\title{
PM NARENDRA MODI'S APPEAL ON FIGHTING AGAINST COVID-19: A STUDY
}

\author{
Gurjeet Kaur \\ Chitkara School of Mass Communication, Chitkara University, Punjab, India \\ Ashutosh Mishra \\ Chitkara School of Mass Communication, Chitkara University, Punjab, India
}

\begin{abstract}
The COVID-19 pandemic is today's biggest public health crisis and the world's largest threat to humanity since the Second World War. COVID-19 has triggered a profound economic crisis, as well as an unprecedented human toll. India is trying to minimise the pandemic's impact and for this Centre and State governments are working hard to sensitise people to keep all the precautions suggested by international and national experts to stop it's spread. The motive of this study is to know whether Prime Minister Narendra Modi is managed to send the right message at the right time. What are the messages and how many times during the lockdown or post lockdown, he addressed the country to instil trust in the people. This research work also focused on to discuss how frequently he has briefed about the measures being taken to curb COVID-19 and to bring the situation under control. In order to study speeches PM Modi delivered during the lockdown, this work aims at conducting the content analysis of Mann ki Baat episodes (March-June 2020) based on the COVID-19 information and all those appeals to the nation that PM made in the 4 months ( March -June 2020) have been used as sample for study. This paper outlines the scope of understanding how PM has inculcated the habit among people about taking precautions to prevent themselves from COVID-19.
\end{abstract}

Keywords: PM Narendra Modi, Speeches, COVID-19, Pandemic, Corona Crisis, Lockdown, Mann ki Baat, Media, Address, Corona Warriors.

\section{MASS COMMUNICATION AS A TOOL FOR DEVELOPMENT}

Communication represents the mechanism of actual human contact. It is a mechanism by which meanings are understood and understandings are attained among people. Media plays vital role in growth and seeks from the target audience to follow a constructive shift in attitude towards intented messages (Choudhary, 2011). Mass media acts as a link between government and the people by placing spotlights on government's actions. Government also takes advantage of the Fourth Pillar of democracy for information dissemination and uses it to involve people in such initiatives which are for the betterment of the society and nation. The media were seen as the 'mobility multipliers' (Schramm 1964) or 'diffusers of innovations' (Rogers 1962, 1983, 2003). India is a developing nation and there are many deep-rooted evils (Dowry, female foeticide, domestic violence, lack of education, unemployment etc.) which are matter of concerns (Kumar, K. J. 2017) . Coronavirus has recently arisen as a huge threat for the world as a whole and so a great deal of responsibility has fallen on the shoulder of the media to make people aware of the symptoms of COVID-19 and how they can defend themselves from this virus.

\section{COVID-19: CURRENT SCENARIO IN INDIA}

Dealing with the unexpected problems caused by the COVID-19 pandemic has taken a huge toll on people all over the planet. A novel coronavirus strain (SARS-CoV-2) was first detected in December 2019 in Wuhan, a town of 11 million people in China's Hubei province, following a pneumonia outbreak with no clear cause. The virus has now spread to more than 200 countries and and the World Health Organization (WHO) described it as a pandemic on 11 March 2020. The first case of COVID-19 was identified on 30 January 2020 in India (Ghosh, 2020). Health and Family Welfare Ministry has confirmed a total of 11,95,703 COVID-19 reported cases, 4,13,288 Active cases and 28,786 deaths In the country as on 20th July 2020. The outbreak and propagation of these viruses will have a major effect on the Indian economy. The outbreak in China could have a profound effect on the Indian economy, especially in the electronics, 
pharmaceuticals and logistics sectors, as commercial ports with China are currently closed (Wang,C. P. 2020) As per the official government guidance, India is planning to fight against the COVID-19, and ignoring or not underlining clear crisis intervention would have highly serious consequences. All of India's neighbouring countries have reported positive cases of COVID-19. In order to guard against the deadly virus, the Indian Government has taken required and stringent steps, including the establishment of health checkpoints between national borders, to test whether citizens entering the country have the virus (Varsha, K. 2020).

Table 1-: Timeline on Covid-19 pandemic cases in India (January -June2020) (Gloria, 2020)

\begin{tabular}{|c|c|}
\hline $\begin{array}{l}\text { Date } \\
(2020)\end{array}$ & Cases \\
\hline January 30 & $1^{\text {st }}$ Reported case \\
\hline March 4 & $\begin{array}{l}\text { Foreign passenger checks are } \\
\text { compulsory at all airports }\end{array}$ \\
\hline March 12 & $1^{\text {st }}$ Death was reported \\
\hline March 13 & $\begin{array}{l}\text { Visa suspension for non-essential } \\
\text { travellers }\end{array}$ \\
\hline March 15 & 100 Reported Cases \\
\hline March 16 & $\begin{array}{l}\text { Passenger boundary crossing } \\
\text { halted }\end{array}$ \\
\hline March 22 & $\begin{array}{l}\text { Janata Curfew: One day } \\
\text { Passenger travel flights } \\
\text { suspended until further notice }\end{array}$ \\
\hline March 25 & $\begin{array}{l}\text { A national lock-down was } \\
\text { enforced until April } 14\end{array}$ \\
\hline March 28 & 1000 cases wereConfirmed \\
\hline March 30 & 100 Recoveries were Confirmed \\
\hline April 5 & 100 Deaths reported \\
\hline April 14 & $\begin{array}{l}\text { 10,000 cases confirmed, } \\
\text { lockdown extended till 3rd May. }\end{array}$ \\
\hline April 19 & 500 Deaths reported \\
\hline April 25 & 5,000 cases confirmed \\
\hline May 1 & $\begin{array}{l}\text { The extended nation wide } \\
\text { lockdown until 17th May }\end{array}$ \\
\hline May 2 & 10000 Patients defeated Corona \\
\hline May 7 & 50,000 Cases were reported \\
\hline May 11 & 20,000 Patients were recovered \\
\hline May 17 & $\begin{array}{l}\text { The Extended Nationwide } \\
\text { Lockdown until 31st May }\end{array}$ \\
\hline May 19 & $\begin{array}{l}\text { 100,000 Corona cases were } \\
\text { confirmed }\end{array}$ \\
\hline May 23 & 50,000 recovieries \\
\hline May 27 & $\begin{array}{l}150000 \text { corona cases were } \\
\text { confirmed }\end{array}$ \\
\hline May 30 & Lockdown in containment areas \\
\hline
\end{tabular}

\begin{tabular}{|l|l|}
\hline & extended till 30th June \\
\hline May 31 & 5,000 deaths due to COVID-19 \\
\hline June 13 & 300,000 reported cases \\
\hline June 17 & 10,000 deaths due to COVID-19 \\
\hline June 27 & 500,000 Confirmed cases \\
\hline June 28 & 321774 Patients defeated Corona \\
\hline June 30 & 585792 reported cases \\
\hline
\end{tabular}

Every phase of this journey has been followed by the media - with numerous news stories, incessant reports and constant updates regarding COVID-19 over the last few weeks. Weather it's electronic media or print media, every sort of media is disseminating information and making people aware of the precautions to be taken against COVID-19 (Varsha, K.2020). Prime Minister Narendra Modi is also advising the country to keep people safe and updated during the public health crisis, either by video messages or through Mann Ki Baat Radio Programme.

\section{Mann Ki Baat-The PM's Show}

Mann Ki Baat- a monthly radio programme in All India Radio ( Akashwani) is an interesting and popular address by the Prime Minister Narendra Modi where he uses this national channel and is relayed by DD's all channels and other TV channels too on the last Sunday of every month. Mann Ki Baat furnishes the common man with the chance to send in their suggestions to PM and also tell him about the issues and themes on which the address should be centred which makes it participatory interface (Ahuja, 2016). The programme began in 2014 and has completed sixty-five broadcasts till date. PM is using this medium at the time of corona crisis to spread awareness .He assured many times in his broadcast that the nation is taking the required steps to curb COVID-19 and trying best possible way to get the situation under control so that citizen may trust and march ahead with crisis situation (Manral, K.2020).

\section{REVIEW OF LITERATURE}

The recent outbreak of COVID-19 in several countries has also triggred the research related to it where researchers have analysed the rise and impact of coronavirus, preparation and preventive measures, future perspective, and effects of lockdown during pandemic. The researchers have done the research to understand the insights of its impact on the masses. One of the researchers 
has reported that almost all parts of the country are struggling with the Corona virus. There is no comprehension of the irony of this modern epidemic, and mortality and morbidity are high across the globe (Varsha, 2020). The Indian Ministry of Sanitation and Family Welfare, the Government of India and ICMR have established guidelines, advice on protocol on social distance, treatment, management, doctrines and doctrines and other credible materials Chatterjee, (K. S. 2020), (MOHFW). Health care staff does its job perfectly well and so is the government but what is important for everybody who is a citizen of India is to maintain social distance and follow advisories strictly from time to time so that we can make way for our dear ones' own lives (Varsha, 2020). In the same way another researcher has observed that one of the most compelling pictures of the 2019 corona virus pandemic (COVID-19) emerged after India's government initiated a 3-week shutdown on March 24, 2020 prompting millions of migrant workers to flee their cities on foot and return to their homes in the countryside in the midst of pledges of casual labourers' financial assistance. Days later, Prime Minister Narendra Modi used his monthly radio address $(M K B)$ to demand forgiveness from the poorest members of society who were left without work and food due to the shutdown (Ranscombe, 2020). Some of the researchers found that psychological influences play a significant role in people's understanding and response to the possibility of the disease and the anxiety that it may impact them directly. The threats are far from symmetrical because underestimating their distribution as a pandemic and not doing anything to control it is much more serious than overspending and being overly vigilant while it is not required. (Petropoulos F, 2020, Wang, C., \& Pan, R.2020, Chatterjee, K. S.2020). Whereas on of the researchers has observed that pandemic COVID-19 had created mayhem around the planet. India is also facing a difficult condition with the number of infected/positive cases increasing every day. This research was performed to investigate the effect of COVID-19 and lockout on people's mental wellbeing. (Wang C. P., 2020).

In addition, the work of other researchers listed above focuses on the study of COVID19. They spoke about the global effects of this pandemic and also discussed prevention steps or future perspectives. Whereas the main objective of this study is to examine the appeals and issues raised by PM Narendra Modi in the battle against COVID-19 during the lockdown/post lockdown (March -June 2020). What are the messages and how many times during the lockdown or post lockdown, he addressed the country to instil trust in the people. It was examined wether people have acknowledged the PM speeches delivered either by video address or $M K B$ radio programme.

\section{SCOPE OF THE STUDY}

This paper aims to evaluate the different speeches delivered by PM Narendra Modi through TV addresses or Mann Ki Baat radio programme (from March to June 2020) in order to make people aware about the impact of Corona-virus and also to minimise the impact of pandemic. This study is helpful in understanding how many times PM has addressesd the nation and what were the key areas which have been discussed by him to bring the situation under control. This paper outlines the scope of understanding how he has inculcated the habit among people about taking precautions to protect themselves from COVID-19.

\section{METHODOLOGY}

In order to conduct research, a streamlined methodology is required for a better outcome. While conducting research on 'PM Narendra Modi's Appeal on Fighting against COVID19 : A Study' qualitative textual analysis emphasizing in-depth examination of the content research methodology has been adopted. Speeches PM Modi delivered during the pandemic have been taken for content analysis including Mann Ki Baat episodes which are largerly based on the COVID-19 information. The speeches he delivered on television from time to time have also been part of the study. There are a total of 6 addresses and 4 episodes of Mann ki Baat radio programme (March-June 2020) in which he discussed COVID-19. These are the various facets and foundations he discussed that would make India self-reliant in COVID-19 times that needs to be examined. Below is a table in which days are mentioned when PM has addressed the nation during Corona-virus Lockdown and Post Lockdown (March- June 2020). 
Table 2. List of PM Narendra Modi's Speeches and MKB Radio Programme during pandemic ( March-June 2020)

\begin{tabular}{|c|c|c|}
\hline $\begin{array}{c}\text { Serial } \\
\text { No. }\end{array}$ & Date & $\begin{array}{c}\text { PM's Address/ } \\
\text { Approximate Duration }\end{array}$ \\
\hline 1 & $\begin{array}{l}\text { March } \\
19\end{array}$ & $\begin{array}{l}\text { Janta curfew announced in } \\
\text { first addressDuration: (29 } \\
\text { Minutes) }\end{array}$ \\
\hline 2 & $\begin{array}{l}\text { March } \\
24\end{array}$ & $\begin{array}{l}\text { 21-day lockdown in second } \\
\text { address Duration: (29 } \\
\text { Minutes) }\end{array}$ \\
\hline 3 & $\begin{array}{l}\text { March } \\
29\end{array}$ & $\begin{array}{c}\text { Mann Ki Baat Address } \\
\text { (30 Minutes) }\end{array}$ \\
\hline 4 & April 3 & $\begin{array}{l}\text { Appeal to light the lamp in } \\
\text { the third address Duration: } \\
\text { (12 Minutes) }\end{array}$ \\
\hline 5 & $\begin{array}{c}\text { April } \\
14\end{array}$ & $\begin{array}{l}\text { Lockdown-2 announced in } \\
\text { fourth address Duration: } \\
\text { (22 Minutes) }\end{array}$ \\
\hline 6 & $\begin{array}{l}\text { April } \\
26\end{array}$ & $\begin{array}{c}\text { Mann Ki Baat Address } \\
\text { (30 Minutes) }\end{array}$ \\
\hline 7 & May 12 & $\begin{array}{c}20 \text { lakh crore economic } \\
\text { package announced, } \\
\text { Lockdown } 4.0 \\
\text { announcedDuration: (34 } \\
\text { Minutes) }\end{array}$ \\
\hline 8 & May & $\begin{array}{c}\text { Mann Ki Baat address } \\
\text { (30 Minutes) }\end{array}$ \\
\hline 9 & June 28 & $\begin{array}{c}\text { Mann Ki Baat Address } \\
\text { (30 Minutes) }\end{array}$ \\
\hline 10 & June 30 & $\begin{array}{c}\text { PM Modi's Appeal (17 } \\
\text { Minutes) }\end{array}$ \\
\hline
\end{tabular}

\section{ANALYSIS AND INTERPRETATION}

The World Health Organization (WHO) has declared COVID-19 as a pandemic on $11^{\text {th }}$ March 2020. The first such case was identified on $30^{\text {th }}$ January 2020 in India. On 24th March 2020 the Government of India announced 21day National lockdown restricting the movement in entire country (Ghosh, 2020). Prime Minister had delivered 6 speeches and 4 Mann Ki Baat radio programme in order to boost up the morale of the masses and to spread awareness about the precautions that can prevent spread of COVID-19. Following is the analysis and interpretation of different topics/issues discussed by PM in his nation's address and in Mann Ki Baat radio programme (March- June 2020). This study has identified various Issues/topics which have been further divided into 2 parts i.e. heading (Theme) and sub headings (Issues) based on the content analysed that has been discussed by PM Narendra Modi.

Analysis of the Content Discussed by PM in his nation's address and in MKB program Fight against Corona is people-driven:-

Prime Minister Narendra Modi appeared on television 6 times to address the country and urged people to stay at home during the Corona pandemic as much as possible. He warned that it would be difficult to save from corona virus scourge if they don't comply with the lockdown law. He also urged people not to ill-treat those who are asked to go on quarantine or isolate themselves to protect other people from getting infected. He urged that they (COVID affected people) need to be shown sympathy and cooperation. In order to curb Covid crisis, Modi announced lockdown ( phase I) on $24^{\text {th }}$ March. He appealed to the people to maintain social distancing, use face mask and keep staying wherever they are in the country. Afterwards, whenever he appeared on TV to make announcements regarding lockdown extension, he always advised to take special care of the elderly, especially those with pre-existing illness (Correspondent, 2020). PM Modi chose Mann Ki Baat Monthly Radio programme to make people aware about the benefits of sanitization. In his $M K B$ address, he encouraged people of India to go for local product and innovation and to fight the pandemic and make India self-reliant. During Unlock 1 and 2 phase, PM said that though some relaxation is given like special trains are made operational, flights have resumed and industry too is returning to normalcy slowly but there should be no laxity in maintaining 6 feet distance and wearing mask. In the 64th episode of MKB scheduled for the 33rd day of the nationwide lockdown, PM Modi said that India's battle against corona-virus is powered by people (Shalini Venugopal, 2020). On 30 th June PM Modi also urged citizen to be extra cautious during Unlock 2.0 and take adequate care of health. He emphasised that determination and patience are the two key factors that will help in combating global pandemic.

Medicine/Vaccine:- While talking about medicine and vaccine, PM said that Science could not find a definite solution yet to save from the Corona pandemic, so it is important that each and every Indian remain alert and 
careful. People with good immunity can defeat this virus; and the Ayush Ministry mentioned some guidelines and Ayurvedic remedies to boost up immunity of pepole. PM also asked for every citizen to download and use Arogya Setu app. US Food and Drug administration had identified Hydroxychlorine as a possible treatment for COVID-19; hence India supplied Anti Malaria drug to 55 Corona virus hit countries. Prime Minister also mentioned that lifeline Udaan undertook to ensure medication is supplied to every corner of the world. Ayushman Bharat Scheme launched one and a half years ago is now more helpful to crores of the beneficiary during this challenging time (Gloria, 2020, Chatterjee, K. S. 2020).

Corona posing a challenge:- Narendra Modi declared Corona virus to be a major challenge for both intelligence, science, the wealthy, the poor, the powerful and the weak. In addition, it is not confined to the borders of any nation nor makes any distinction on regional and religious grounds. According to World Health Organisation, a person infected with Corona may seem to be completely healthy in the beginning since it is not evident and if he is infected may transmit it to hundreds of people within the span of 7 to 10 days who come to close contact with him as it is a chain reaction and if it spreads further, the tracing of people who came in contact with the initial affected one will be almost impossible. PM also noted that the spread of the disease in other countries has experienced almost an explosion after the initial days, despite of having the best healthcare services. Though in India, due to lockdown, it is not spreading at a fast pace but if people become careless then it can be a challenge for everyone also (Chatterjee, 2020) .

Government \& administration's role:- PM appreciated many times the efforts made by all States and Central government to combat COVID-19. Under the leadership of the Finance Minister, the Government set up a COVID-19 Economic Response Task Force. He mentioned in $M K B$ program how the government is making efforts and provided 32 crore people with financial support worth Rs 29,352 crore. The police personnel have been working day and night to ensure discipline and helping the needy in this crisis. The government has established a Digital Platform called COVID warriors.gov.in and these warriors are of great help at the local level in planning and executing crisis management plans. PM Modi urged the poor to get themselves enrolled and extend their helping hand so that fight against Corona could be won. Likewise, during the lockout, railways operate tirelessly so that the common man across the country doesn't have to face problems (Manral, 2020).

Boost up morale of COVID warriors:- PM urged all Indians on March 22 to stand at their doors, balconies, windows of their houses, clap for those warriors and salute their services to raise the morale of those who have served others selflessly, without thinking for themselves. Whether they are doctors, nurses, police personnel, security guards, airline employees, sanitation workers, media people, milkman, driver, bank personnel they all deserve standing ovation. The government has declared a health insurance cover of up to Rs. 50 lakhs so these COVID warriors so that they can lead the country more comfortably in this fight. He also thanked the private sector for standing shoulder to shoulder with the government in times of crisis (Online, 2020). The government declared that the Centre had made provision of Rs 15,000 for the healthcare infrastructure of the country. The Ordinance was issued to ensure the safety of COVID warriors, and provides for serious punishment for those who threaten, injure or engage in violence against warriors of Corona. He also emphasized that the year -2020 is being celebrated as the Nurse \& Midwife 's International Year.

Cultural Reflection:- Prime Minister Narendra Modi had identified the connection between culture, festivals and the challenging times of today. While mentioning about Navratri in the month of March, he said it's a festival of worshipping SHAKTI so India moves forward with full shakti, full power and energy to beat COVID-19. Talking about Akshaya Tritia he said it holds a special significance for us. In these troubled times, it tells us that our soul, our life force, is Akshaya, and the human spirit of fighting and fighting against them is exhaustible, no matter how many difficulties our path blocks. This festival presents an opportunity to understand the value of charity, of giving; hence everyone should help each other in this challenging time by feeding or helping the needy. He also mentioned the role of Yoga and Ayurveda 
during present Corona pandemic (WebDesk, 2020). The Ministry of Ayush also did unique experiment to increase the practice of Yoga in one's life by initiating Vlog competition entitled My Life My Yoga. Since the entire world is focussed on increasing their immunity, the demand for spices including ginger, turmeric etc. has increased not only in Asia but all over the World. Irrespective of the magnitude of the calamity confronting India's sanskar (value) of extending help, spirit of the way of life inspires one and all to serve selflessly.

Inspiring Thoughts:- In $M K B$ programme he had a conversation with those who had defeated Corona by abiding the instructions. PM asked them to share their stories on social media so that others get motivated. He also talked to doctors who had mentioned that counselling and motivation play important role in treating Corona patients. In $M K B$ radio programme, people have sent him letters and shared how they are utilising this quarantine time by taking up hobbies. PM Modi also pitched for 9 minute show of solidarity and asked the public to light diyas, candles, torches to mark the national fight against corona virus outbreak. He mentioned that fighting against corona is people driven initiative. So taali, thali and diyas have kept spirits high. He appreciated the efforts made by citizens like KC Mohan from Madurai, Gautam Das from Agartala, Divyang Raju from Pathankot, Rajendra Yadav from Nasik, Women self-help groups in village or small towns who are making thousands of masks on a daily basis. He said that India has always transformed adversities into stepping stones to success. While talking about the sacrifices made by soldiers at Gallwan valley, PM said that a self-reliant India would be a tribute to the martyrs in the deepest sense. In this way, he motivated Indians to take strides towards self-reliance. In his $30^{\text {th }}$ June address, PM said that India is still comparatively stable in dealing with Corona situation. He reiterated that timely decisions and measures had played a great role in this. He appreciated the innovative ideas adopted by offices, educational institutions and medical sector.

Migrant Crisis:- Following Modi's address of $14^{\text {th }}$ April, an unprecedented situation emerged in Mumbai when a large number of migrant labourers came out on the road in
Bandra (West) bus depot near the railway station asking for transport arrangements to go to their native country. Following the intervention of additional force to contain the situation the crowd was eventually dispersed.The government also announced that Rs 29, 352 crore financial assistance was given to more than 32 million-poor citizens as on April 13 (Shankar Jha, 2020). He showed his concern for daily wagers and migrant labourers while delivering speech during lockdown. He said that there is no section in country that is unaffected by the difficulties caused by pandemic but the worst affected are the labourers and the poor. He mentioned that safe transportation of lakhs of workers in trains and buses, taking care of their food, arranging for their quarantine in each district, monitoring, screening and treatment is an ongoing operation and recently Central government's decisions have opened up large positions of self-employment, village and small-scale work. PM Narendra Modi announced in his speech on June 30 that free ration scheme Pradhan Mantri Garib Kalyan Yojana - will be extended to support needy and migrant workers during the upcoming Indian festival season until the end of November 2020.The Prime Minister has promised that until after Diwali and Chhath Puja, the government will continue to provide the needy families with necessary ration/ food. In fact, Prime Minister announced comprehensive introduction of the 'One Country, One Ration' card program to assist migrant workers (Ranscombe, 2020).

Self Reliance:- In his various address PM Modi said that self-reliance can be achieved with self-confidence and powerful action. Everyone needs to behave aggressively to succeed in the global supply chain. This crisis is so severe that many institutions have broken, but the power of employees and the vulnerable is witnessed at the same time. PM said that from globalized wealth to human capital globalization, the World's outlook for India is being changed since end of open defecation, fight against $\mathrm{TB}$, pulse polio campaign's success and India's determination to overcome all odds and the world is convinced that Indians will contribute to great extent in changing society. In his speech, which included the announcement of the Rs 20 lakh crore economic package, Modi stressed the importance of self-reliance, equivalent to 
10 per cent of the country's Gross Domestic Product (GDP) (Shalini Venugopal, 2020). For a self-reliant India, namely: economy, infrastructure, technology-driven framework, vibrant demography, and demand, the Prime Minister identified "five pillars." Those are well-crafted phrases that take economic and security problems into account and not mere political rhetoric. His second slogan, "local mein vocal," is specifically intended to inspire people to prefer products manufactured locally and reduce their cravings for international brands. It has opened up a strong possibility for the government to promote substitution of low-tech products imported from various countries, especially China. The government may consider a sharp rise in custom duties on a range of imports to encourage manufacturers to manufacture them at lower prices locally.

Guiding Mantras:- In the wake of COVID-19, through MKB or his video messages Narender Modi has introduced Mantras that should guide people in dealing with the impact of this pandemic. Such slogans/Mantras will help in fighting against COVID-19.

A. Hum Swasth, Toh Jag Swasth'.

B. Evam Evam Vikar, api tarunha Saadhyate Sukham" which means, an illness and its scourge should be nipped in the bud itself.

C. Aarogyam Param Bhagyam, Swasthyam Sarwaarth Sadhanam". It says, the greatest blessing is good health. Health is the world's best means of finding happiness.

D. Na Aatmarthan Na Api Kaamartham Atbhoot Dayam Prati Vartate yat Chikitsaym Sa Savarma Iti Vartate

It says, the best Doctor is the one who works for the well-being of his patient in a spirit of service and compassion, without greed, monetary or otherwise.

E. Lakshman Rekha' at your doorsteps.

F. Corona, i.e., Koi Road pe Na Nikle (no one should go out on the road).

G. Jaan hai toh Jahaan hai

H. Agni: Shesham Rina: Shesham,

Vyadhi: SheshamTathaivacha.

Punah: Punah: Pravardheta,

Tasmaat Shesham na Kaaryet || When taken lightly, it means Fire, Debt and Illness develop again at the first opportunity, assuming dangerous proportions- so it is necessary to handle them fully!

I. Do Gaz Doori, Bahut Hai Zaroori.
J. Sarvam Aatmam Vasham Sukham. What is in your hold brings you joy. We need to move on with fresh energies.

K. Sewa Paramo Dharmah; service is a joy in itself....service is a satisfaction in itself.

L.Vidya vivadaya dhanam madaay, shaktih pareshaan paripeednaya

Khalasya sadhoh vipareetam etat, gyaanay daanay ch rakshanay. It means that a person who is wicked by nature is using education to foster conflict, wealth for conceit, and strength to disturb others? Whereas a gentleman uses intelligence awareness, wealth to support and power to defend.

M. Swabhavam: na Jahati eva, sadhuh: aapadratopi san 1

Karpoor: Pawak saprishta: Saurabham labhteetrama | |

Which means, just like camphor does not abandon its fragrance even while burning in fire, the virtuous do not forsake their qualities or their true nature while facing a disaster (Correspondent, 2020; Gloria, 2020).

\section{GRAPHICAL REPRESENTATION}

Through graphical representation, this study has also shown the COVID-19 reported cases, active cases and death rates during 6 times PM Modi's nation address on television and 4 times on radio programme through $M K B$ during lockdown/ postlockdown (March-June 2020)

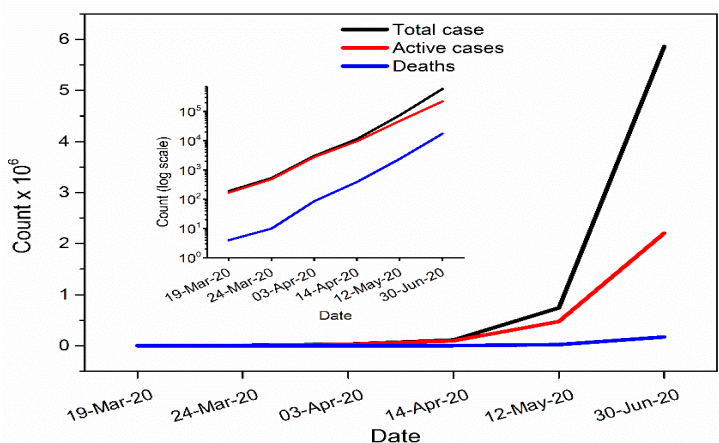

Fig.1: Analyses of COVID-19 reported cases, Active cases and Death rates during Lockdown and Post-Lockdown period.

Fig.1 shows the count of total cases, active cases and deaths for the period of 19-Mar-20 to 30-Jun 20 in both linear scale as well as log scale. In the initial days, i.e. from 19-Mar-20 to 03-Apr-20, the increase in the above mentioned count was low.. However, it increases significantly after that. The 
researcher has selected those dates when Narendra Modi addressed the nation regarding COVID-19 and appeared on TV for the same. Quantitatively the count of total cases, active cases and deaths rises from 3059, 2781 and 86 to 11487, 9735 and 393, respectively in the period of 03-Apr-2020 to 14Apr 20. Further, these values are increased to 11487, 9735 and 393 till 12-May-20, and thereafter it reached the peak value of 585792, 220546 and 17410 for the last time period under consideration, i.e. 30-Jun-20". The graphs shows that from lockdown to post lockdown/ unlock ,the cases kept increasing. When the relaxation was given in Lockdown time , the ratio of reported cases increased day by day but not in a way as it was in other countries. To some extent India was able to curb COVID-19 spread by imposing lockdown at the right time.

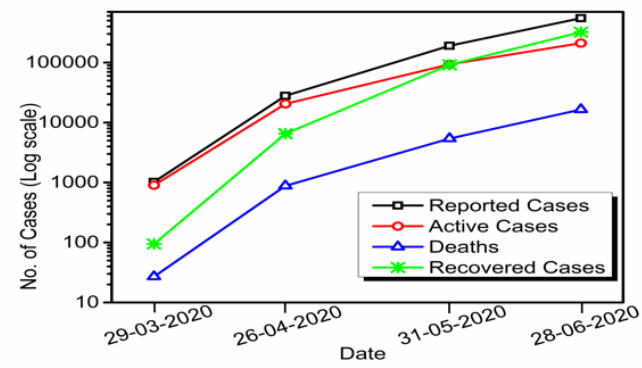

Figure 2. Count of reported cases, Deaths, Active cases and Recovered cases of COVID19 during PM's MKB Address.

Fig.2 shows the number of cases reported along with active cases, deaths and the recovered cases from $29^{\text {th }}$ March to $28^{\text {th }}$ June 2020 .The researcher has selected those dates when PM Modi addressed the nation regarding COVID-19 through Mann Ki Baat programme. It shows that from $29^{\text {th }}$ March to $26^{\text {th }}$ April, 26,866 new cases of Corona patients were reported which reached to $1,62,719$ by $31^{\text {st }}$ May 2020 . Thereafter by $28^{\text {th }}$ June, $2,58,588$ new cases were reported resulting into total of 5,49,197 reported cases till the end of June 2020. The plot also shows the active cases from $29^{\text {th }}$ March to $28^{\text {th }}$ June 2020. It reports that on $2^{\text {th }}$ March there were only 902 active cases which were increased by 19,584 on $26^{\text {th }}$ April and further by 72,863 by $31^{\text {st }}$ May. It reached to $2,10,936$ on $28^{\text {th }}$ June 2020. The number of deaths that occur from March end to June end 2020 has also been depicted in Fig.2 It shows that by the end of March 27, death cases were reported 881
(26 ${ }^{\text {th }}$ April) ， 5408 (31 May) and 16487 (28 $8^{\text {th }}$ June). It has been evaluated that the recovery rate is also significant and the same is shown in Fig.2. It reports that 95 people recovered till 29th March 2020, while by $26^{\text {th }}$ April, 6,523 people recovered from Corona . The recovered cases increased almost parallelly with the reported cases (depicted by the green and black lines). The recovered cases increased to 91,852 ( by 31 ${ }^{\text {st }}$ May ) and 3,21,774 (by $28^{\text {th }}$ June).

\section{CONCLUSION}

We can state that irrespective of the opposition leadership's penchant for giving a political tinge the fact is that the Prime Minister Narendra Modi has addressed the calamitous pandemic in a very human and humane manner. As a result, his word of mouth is being taken as verdict by the people e.g. mass compliance to his appeal with regard to boosting morale of the Corona Warriors by clapping, beating the thalis etc. It was innovative on Mr. Modi's part to call them warriors- a gesture potent enough to equip those on Corona front with a soldierly spirit. His announcement of support for the poor and needy up to Diwali/Chhath puja etc. was well received so that people should not lose the festive spirit and a feel that this tough time will also pass if the government is trying its best to support them with food, loan and other measures. The very act of addressing the nation again and again over the issue of the pandemic shows PM's concern for the countrymen. The motive of Narendra Modi's address was to make people habitual of maintaining hygiene to protect themselves or others from Corona virus and to curb the spread of this pandemic. He introduced 21day lockdown period learning from the mistakes of countries like Italy, Spain, United Kingdom and the USA who have not followed social distancing standards and lost many lives too. His swift decision-making in the midst of the worldwide turmoil has helped India prolong the second stage of the pandemic. This was introduced without taking into account the consequences of the same. One example is the relocation of migrant labour. India has so far reported more than 12 lakh COVID-19 cases ( by 22 July 2020) rendering it the third worst-hit nation in the world. Major cities like Delhi and Mumbai are especially hard hit with hospitals unable to treat patients with serious illnesses. The new 
increase in infections follows a two-and-a-halfmonth shutdown across India that began on March 25 and had seriously affected the economy and livelihood. PM Narendra Modi's appeal to the nation on fighting Corona on different occasions has reached to people in right perspective and by slowing down its spread the nation was able to manage it resourses and got time for preparation in health sector front apart from sensitising people to be safe.

\section{Conflict of Interest Argument}

In respect of the work, the author and/or its publication, the authors claimed that there were no possible conflicts of interest.

\section{Financial assistance}

For research, authorship and/or publication of this paper, the writer(s) did not receive funding.

\section{REFERENCES}

Akashvanisamvaad. (2014, April 26). 7 Historic All India Radio (AIR) Broadcasts In India,. Retrieved August 14, 2019, from Akashvanisamvaad: http://akashvanisamvaad.blogspot.com/ 2014/04/7-historic-all-india-radio-air.html

Apeksha, D. (2019, September 29). Analysing four years of "Mann Ki Baat. Retrieved August 16, 2019, from mapsofindia.com: https://www.mapsofindia.com/myindia/imo/analysing-four-years-of-mannki-baat

Asemah, E. S. (2013). Radio as atool for rural development in Nigeria:Prospects and challenges. An International journal of Arts and Humanities, Vol 2(1), Issue 5,pp17-35.

Chatterjee, K. S. (2020). Coronavirus disease 2019 in India: Post-lockdown scenarios and provisioning for health care. Medical Journal Armed Forces India, pp 1-12.

Choudhary, P. (2011). Media in Development Communication. Global Media Journal, Vol 2, India, pp 1-13.

Correspondent, H. (2020, April 3). Corona Update. Retrieved from Hindustan Times: https://www.hindustantimes.com/indianews/coronavirus-update-10-appeals-pmmodi-has-made-in-fight-against-covid19/story-u1hbkf4So9SxLNOgnuw3fJ.html
Durgesh, s. (2016). Big data for geo-political analysis: Application on Narendra Modi's Speeches. International journal of science technologyEengineering., Vol3, No.3,pp 207210.

Gandhi AP, B. J. (2017). Mann Ki Baat- present and Future. J. Adv. Res. Jour. Mass Comm., pp 1-4.

Ghosh, D. (2020, April 3). NDTV Corona Virus. Retrieved from NDTV.com: https://www.ndtv.com/india-news/pmnarendra-modi-on-coronavirus-lockdownlight-candles-use-mobile-flashlights-onsunday-at-9-pm-2205306

Gloria, S. (2020, July 2). Covid-19: Here's a timeline of events since lockdown was imposed in India. Retrieved from Business Standard: https://www.businessstandard.com/article/currentaffairs/here-s-a-timeline-of-events-sincelockdown-was-imposed-in-india120070201413_1.html

Gyan, v. (2018, November 25). Mann Ki Baat led to mass movements in the time of social media, says PM Modi. Retrieved September 4, 2019, from LiveMint: https://www.livemint.com/Politics/Tly3 Tq9GMMqUQKmYmgFiKJ/Mann-KiBaat-led-to-mass-movements-in-the-timeof-social-med.html.

Jaffrelot, C. (2015). "Narendra Modi and the power of television in Gujarat. Television $\mathcal{E}$ New Media, Vol-16,(4),pp 346-353.

Jsna, J. (2016). Mann ki baat: Radio as a medium of communication by the Indian premier,narendra Modi. Asian politics $\mathcal{E}$ policy, Vol 8,Issue 3,pp520-524.

Laghat, G. (2020, March 27). PM Modi's 21-day 'complete lockdown' address most watched event on TV. Retrieved from The Economic Times:

https://economictimes.indiatimes.com/n ews/politics-and-nation/pm-modis-21day-complete-lockdown-address-mostwatched-event-ontv/articleshow/74844916.cms

Lazzari Z. (2019, February 20). "Radio communication $\mathcal{E}$ its uses",. Retrieved January 26, 2019, from https://www.techwalla.com/articles/rad io-communication-its-uses. 
Manral, K. (2020, May 12). rom March 19 to May 12, Here is How Long Each of PM Modi's Addresses to Nation on COVID-19 Lasted. Retrieved from India.com: https://www.india.com/news/india/fro m-march-19-to-may-12-here-is-how-longeach-of-pm-modis-addresses-to-nation-oncovid-19-lasted-4027406/

HR, M. (2016). Reviving public service broadcasting for governance-A case study in India. in proceeding of 12th International conference on humanities $\mathcal{E}$ social science (pp 98-108). Thailand. : Khon kaen university Thailand. .

Mehar, K. (2019). Analysing the role of the radio programme 'Mann ki Baat' as a tool for political propaganda and persuasion by Prime Miister Narendra Modi. Bengaluru,India: department of media studies,Christ deemed to be university.

Modi, N. (2020, March, April, May, June 29, 26,31,28). Mann Ki Baat. Retrieved from NaMo App: https://www.narendramodi.in/ mann-kibaat\#0

N.S, A. (2020). China's Response to the COVID-19 Outbreak: A Model for Epidemic Preparedness and Management. Dubai Medical Research, pp1-12.

Online, M. (2020, April 13). Coronavirus lockdown: PM Narendra Modi to address nation on. Retrieved from Mumbi Mirror: https://mumbaimirror.indiatimes.com/co ronavirus/news/coronavirus-lockdownpm-narendra-modi-to-address-nation-onapril-14/articleshow/75121174.cms

Patil, D. M. (2011). Recent Trends of Print Media in Development Communication. Global Media Journal, Vol 2, India, pp 1-20.

Ranscombe, P. (2020). Rural areas at risk during COVID-19 pandemic. NewsDesk, Vol 20, Issue 5, pp 545-553.

Shalini Venugopal, H. K. (2020, March 24). Modi Orders 3-Week Total Lockdown for All 1.3 Billion Indians. Retrieved from The
NewYok

Times:

https://www.nytimes.com/2020/03/24/

world/asia/india-coronavirus-

lockdown.html

Shankar Jha, P. (2020, June 12). The Lockdown Backfired and Modi Has Only Himself to Blame. Retrieved from The Wire: https://thewire.in/economy/thelockdown-that-backfired

Subir, S. (2017). fragile hegemony:Modi,Social Media and competitive electoral populism in india. International journal of communication, Vol 11,pp 4158-4180.

Varsha, K. (2020). Novel CoronaVirus ( COVID-19) in India: Current Scenario . International Journal of Research and Review, Vol 7, pp 435- 447.

Vasudha, V. (2018, November 29). AIR gets a feel of listeners' Mann Ki Baat via survey. Retrieved September 4, 2019, from The Economics times: https://economictimes.indiatimes.com/n ews/politics-and-nation/air-gets-a-feel-oflisteners-mann-ki-baat-viasurvey/articleshow/66858205.cms.

Wang, C. P. (2020). Immediate Psychological Responses and Associated Factors during the Initial Stage of the 2019 Coronavirus Disease (COVID-19) Epidemic among the General Population in China. International Journal of Environmental Research and Public Health, Vol 17, Issue 5, pp 1729.

Wang, C., \& Pan, R. (2020). A longitudinal study on the mental health of general population during the COVID-19 epidemic in China. Elesvier( Brain, Behaviour and immunity, Vol 87, pp 40-48.

WebDesk, I. T. (2020, March 20). PM Narendra Modi on coronavirus: Read prime minister's full speech on Covid-19 outbreak. Retrieved from India Today: https://www.indiatoday.in/india/story/ pm-narendra-modi-on-coronavirus-readprime-minister-full-speech-on-covid-19outbreak-1657677-2020-03-20 